\title{
KARAKTERISTIK GENETIK INDUK RAJUNGAN, Portunus pelagicus DARI BEBERAPA PERAIRAN MELALUI ANALISIS RFLP MT-DNA
}

\author{
Sari Budi Moria, Haryanti, Gusti Ngurah Permana, dan Bambang Susanto
}

\begin{abstract}
ABSTRAK
Karakteristik genetik induk rajungan yang disampling dari beberapa perairan Cilacap (Jawa Tengah), Situbondo (Jawa Timur), Jembrana (Bali), dan P. Saugi (Sulawesi Selatan) telah diteliti dengan menggunakan metode RFLP (Restriction Fragment Length Polymorphism) mitochondriaDNA (mt-DNA). Hasil yang diperoleh dari amplifikasi PCR dengan primer universal menghasilkan pita tunggal dengan berat molekul sebesar $450 \mathrm{bp}$. Pemotongan dengan enzim restriksi Sau $3 \mathrm{Al}$ dan Dra / menunjukkan bahwa variasi genetik tertinggi terdapat pada populasi dari perairan Cilacap (Jawa Tengah) yaitu sebesar 0,14. Populasi rajungan dari perairan Situbondo (Jawa Timur) dan Jembrana (Bali) mempunyai jarak genetik yang dekat $(0,0013)$, sedangkan populasi rajungan dari perairan P. Saugi (Sulawesi Selatan) mempunyai jarak genetik yang paling jauh $(0,002)$.
\end{abstract}

ABSTRACT: Genetic characterization of swimming blue crab broodstock, Portunus pelagicus from different waters through RFLP Mt-DNA analysis. By: Sari Budi Moria, Haryanti, Gusti Ngurah Permana, and Bambang Susanto

Genetic characterization of swimming blue crab brood stock which was taken from different waters i.e. Cilacap (Central Java), Situbondo (East Java), Jembrana (Bali), and Saugi Island (South Sulawesi) have been analyzed by using RFLP (Restriction Fragment Length Polymorphism) mitochondria-DNA (mt-DNA). The result of PCR amplification using universal primer obtained single band with molecule weight of $450 \mathrm{bp}$. Digestion with Sau 3Al and Dra I restriction enzyme showed that the highest genetic variation was blue swimming crab brood stock population from Cilacap (Central Java) that is 0.14. Genetic distance of brood stocks from East Java and Bali is closed (0.0013) while brood stocks from South Sulawesi have the farthest genetic distance (0.002).

KEYWORDS: Portunus pelagicus, RFLP Mt-DNA, genetic characterization

\section{PENDAHULUAN}

Satu di antara komoditas perikanan yang memiliki nilai ekonomis tinggi dan saat ini sedang dikembangkan adalah rajungan (Portunus pelagicus). Permintaan daging rajungan cukup tinggi baik lokal maupun ekspor, sementara potensi rajungan di sebagian perairan Indonesia pada tahun 2000 semakin menurun (Juwana, 2002). Sampai saat ini seluruh ekspor rajungan masih merupakan hasil tangkapan dari alam, yang dikhawatirkan akan mempengaruhi populasi di alam (Supriyatna, 1999). Upaya untuk memenuhi permintaan daging rajungan harus sudah mulai dipenuhi dengan hasil budi daya di tambak yang tentu saja diawali dengan penyediaan benih yang cukup dan berkesinambungan.

Penelitian tentang produksi massal benih rajungan di Balai Besar Riset Perikanan Budidaya Laut, GondolBali masih relatif baru bila dibandingkan dengan kepiting bakau yang telah lebih lama dilakukan (Rusdi et al., 1993; Yunus et al., 1996; Rusdi, 1999). Masalah utama dalam budi daya adalah benih yang terbatas baik kuantitas maupun kualitasnya. Keberhasilan pembenihan juga masih bervariasi karena banyak faktor yang berhubungan dengan keadaan ini, di antaranya teknik pembenihan yang belum mantap, kualitas induk secara genetik belum diketahui, serta masalah non teknis lainnya. Agar pembenihan rajungan cepat memberikan keberhasilan, maka perlu dilakukan inventarisasi dan evaluasi karakteristik genetik rajungan dari alam yang digunakan sebagai bahan pertimbangan dalam pelaksanaan breeding program.

Pembenihan dapat menurunkan keragaman genetik pada turunan berikutnya dan indikasi terjadinya penurunan keragaman genetik ditentukan oleh lokus polimorfik, heterosigositas, dan jumlah alel per lokus (Taniguchi et al., 1983; Sugama \& Prijono, 1998; Benzie \& Williams, 1996). Penurunan keragaman genetik akibat hilangnya alel-alel dari hasil

Peneliti pada Balai Besar Riset Perikanan Budidaya Laut, Gondol 
pembenihan dapat menghambat pertumbuhan, rentan terhadap serangan penyakit, serta perubahan lingkungan (Rayman \& Stahl, 1980; Leary et al., 1985). Oleh karena itu, upaya penelusuran dan inventarisasi karakter genetik rajungan pada tingkat molekuler dengan metode Restriction Fragment Length Polymorphism (RFLP) mt-DNA perlu diidentifikasi untuk mendapatkan informasi hubungan dan struktur populasinya di alam. Dengan mengetahui karakter genetik induk rajungan dari alam, dapat menjadi dasar seleksi dalam menentukan sumber induk yang akan digunakan untuk produksi benih.

\section{BAHAN DAN METODE}

\section{Hewan Uji}

Hewan uji yang digunakan dalam riset ini adalah rajungan (Portunus pelagicus) hasil tangkapan di 4 (empat) lokasi perairan yang merupakan sumber induk rajungan yaitu Cilacap (Jawa Tengah), Situbondo (Jawa Timur), Jembrana (Bali), dan P. Saugi (Sulawesi Selatan). Jumlah sampel setiap lokasi perairan sebanyak 20 ekor dengan ukuran panjang karapas, lebar karapas, dan bobot seperti terlihat pada Tabel 1.

\section{Ekstraksi DNA}

DNA rajungan diekstraksi dari daging dengan mengikuti modifikasi metode Ovenden (2000). Daging rajungan dimasukkan ke dalam tabung eppendorf 1,5 $\mathrm{mL}$ yang telah berisi $500 \mathrm{~mL}$ larutan $10 \%$ Chelex100 , kemudian ditambahkan $5 \mathrm{~mL}$ proteinase kinase $(10 \mathrm{mg} / \mathrm{mL})$ dan diinkubasikan pada suhu $55^{\circ} \mathrm{C}$ dalam water bath selama 3 jam. Setelah 3 jam, larutan ini dipanaskan lagi pada suhu $89^{\circ} \mathrm{C}$ selama 8 menit. Sebelum ditambahkan $55 \mathrm{~mL}$ TE (Tris-EDTA) buffer

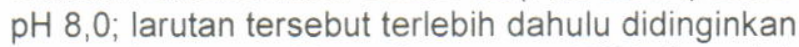
pada suhu kamar. Kemudian genom DNA diperoleh dengan cara sentrifugasi selama 5 menit pada kecepatan 13.000 rpm. Larutan pada lapisan atas yang berwarna jernih merupakan genom DNA, kemudian dipindahkan kedalam tabung eppendorf baru dan disimpan pada suhu $-20^{\circ} \mathrm{C}$ untuk analisis lebih lanjut.

\section{Amplifikasi PCR genom DNA}

Primer yang digunakan untuk mengamplifikasi template mt-DNA sampel rajungan adalah primer $12 \mathrm{Sai}$ (5'-AAACTAGGATTAGATACCCTATTAT-3') dan $12 \mathrm{Sbi}$ (5'AAGAGCGACGGGCGATGTGT'3). Amplifikasi template menggunakan Polymerase Chain Reaction (PCR) dengan komposisi reaksi (Qiagen): Aquadest, 10xPCR buffer; $0.25 \mathrm{mM}$ dNTP mix; Primer (10 mM), Q-solution, Taq polymerase dengan total volume $25 \mu \mathrm{L}$. Siklus PCR yang digunakan dalam amplifikasi adalah 30 siklus penggandaan yang terdiri atas $94^{\circ} \mathrm{C}$ selama 2 menit, $55^{\circ} \mathrm{C}$ selama 30 detik, dan $72^{\circ} \mathrm{C}$ selama 1 menit 30 detik. Selanjutnya satu siklus terakhir $72^{\circ} \mathrm{C}$ selama 10 menit. Untuk mengetahui pola pita tunggal yang dihasilkan dari amplifikasi mt-DNA, maka digunakan 1\% agarose gel dalam 1xTBE (Tris Boric Acid EDTA) buffer dengan lama electrophoresis 30 menit. Sebagai molekuler marker digunakan DNA ladder $100 \mathrm{bp}$, sedangkan untuk pewarnaan digunakan ethidium bromide dengan cara perendaman selama 10 menit. Hasil yang diperoleh diamati di bawah UV transilluminator dan didokumentasikan dengan gel kamera.

\section{Restriction Fragment Length Polymorphism (RFLP)}

Untuk mengetahui polimorfik sampel dan marker enzim restriksi, template mt-DNA produk amplifikasi PCR dipotong dengan enzim restriksi Sau 3AI ('GATC), Dra I (GCG'C), Hinc I (CATG'), dan Ase I (AG'CT). Pemotongan template mt-DNA diawali dengan menyiapkan larutan $10 \times$ buffer, $100 \times$ BSA, enzim restriksi dan aquades serta template mt-DNA produk amplifikasi PCR dengan konsentrasi tertentu. Selanjutnya diinkubasi dalam waterbath dengan suhu $37^{\circ} \mathrm{C}$ selama $3-4$ jam.

Tabel 1. Rata-rata kisaran bobot $(\mathrm{g})$, panjang karapas $(\mathrm{mm})$, dan lebar karapas $(\mathrm{mm})$ sampel rajungan, $P$. pelagicus

Table 1. The range averages of weight $(\mathrm{g})$, carapace length $(\mathrm{mm})$, and carapace width of swimming blue crab, P. pelagicus

\begin{tabular}{lcccc}
\hline $\begin{array}{c}\text { Lokasi } \\
\text { Locations }\end{array}$ & $\begin{array}{c}\text { Jumlah sampel } \\
\text { Number of } \\
\text { samples }\end{array}$ & $\begin{array}{c}\text { Bobot tubuh } \\
\text { Body weight } \\
\text { (g) } \\
\pm \text { SD }\end{array}$ & $\begin{array}{c}\text { Panjang karapas } \\
\text { Mean carapace } \\
\text { length }(\mathbf{m m}) \\
\pm \text { SD }\end{array}$ & $\begin{array}{c}\text { Lebar karapas } \\
\text { Mean carapace } \\
\text { width }(\mathbf{m m}) \\
\pm \text { SD }\end{array}$ \\
\hline Cilacap, Jateng & 20 & $173.58 \pm 61.48$ & $59.77 \pm 7.36$ & $135.69 \pm 16.44$ \\
Situbondo, Jatim & 20 & $75.26 \pm 44.75$ & $44.72 \pm 10.74$ & $101.32 \pm 20.35$ \\
Jembrana, Bali & 20 & $177.58 \pm 71.94$ & $58.66 \pm 7.43$ & $130.01 \pm 14.96$ \\
P. Saugi, Sulsel & 20 & $113.00 \pm 38.75$ & $51.44 \pm 5.08$ & $119.70 \pm 10.59$ \\
\hline
\end{tabular}


Dengan menggunakan 1,5\% agarose gel dalam 1XTBE bufferdan dielektroforesis selama 35 menit serta pewamaan dengan ethidium bromide selama 10 menit, maka akan diperoleh potongan fragmen dari masingmasing template mt-DNA. Sebagai molekuler marker digunakan DNA ladder $100 \mathrm{bp}$, sedangkan untuk kontrol digunakan template mt-DNA yang tidak mengalami pemotongan. Hasil yang diperoleh diamati di bawah UV transilluminatorpada $320 \mathrm{~nm}$ dan didokumentasikan dengan gel kamera. Untuk mengkonfirmasi frekuensi genotip dilakukan analisis Chi-square dari hukum Hardy-Weinberg dengan menggunakan software GENPOP Program (Raymond \& Rousset, 1995). Dengan hasil analisis ini akan diperoleh karakter genetik meliputi susunan berat molekul fragmen DNA, heterosigositas, dan jarak genetik (Roger's, 1972).

\section{Analisis data}

Uji Chi-square digunakan untuk menentukan keabsahan genotip yang teramati, yang diduga dengan hukum keseimbangan Hardy-Weinberg dengan derajat bebas $(\mathrm{df})=(\mathrm{n} 2-\mathrm{n}) / 2$ di mana $\mathrm{n}$ : jumlah alel per lokus (Sokal \& Rohlf, 1981). Heterosigositas teramati $(\mathrm{Ho})$ diketahui dengan menghitung genotip yang teramati, yaitu menjumlah individu yang heterosigot dengan jumlah individu yang dianalisis.

\section{HASIL DAN BAHASAN}

Hasil amplifikasi mt-DNA dengan menggunakan primer 12 Sai dan 12 Sbi menunjukkan panjang pita sebesar 450 bp (Gambar 1).

Dari empat enzim restriksi yang digunakan untuk memotong template mt-DNA tersebut (Sau 3AI, Dra I, Hinc I, dan Ase I, hanya 2 enzim yang mempunyai sisi pemotongan yaitu Sau 3A/dan Dra / (Gambar 2).

Pemotongan fragmen mt-DNA dengan menggunakan enzim Dra / menghasilkan dua jenis pola restriksi, sedangkan enzim Sau $3 A I$ hanya mempunyai satu pola restriksi (Gambar 3).

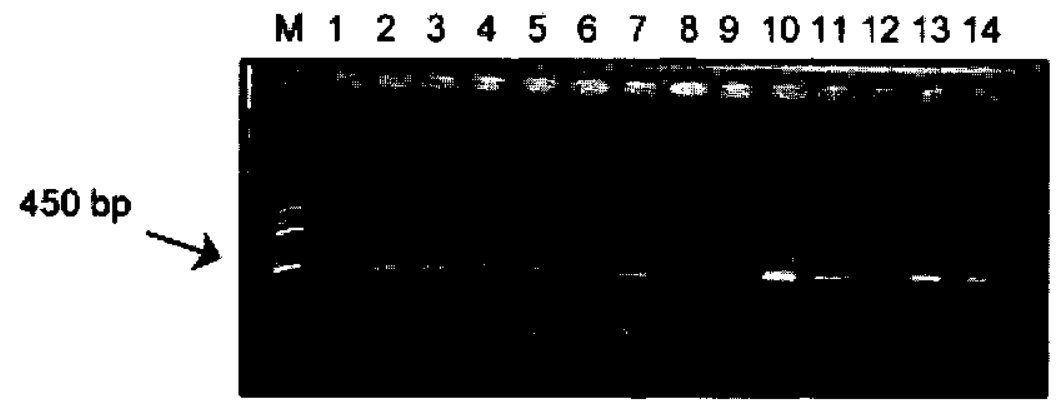

Gambar 1. Pita tunggal template mt-DNA pada rajungan, $P$. pelagicus yang diamplifikasi dengan primer 12 Sai dan 12 Sbi (M; marker $100 \mathrm{bp}$; 1-14 sampel)

Figure 1. Single band $m$ t DNA template of swimming blue crab P. pelagicus amplified by using 12 Sai dan 12 Sbi primer (M; marker 100 bp; 1-14 samples)

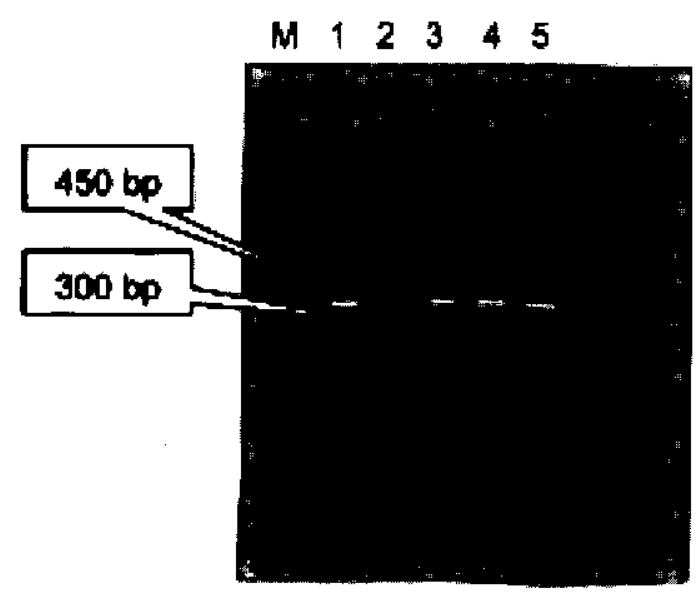

Gambar 2. Pemotongan template mt-DNA dengan enzim restriksi Sau 3AI, Dra I, Hinc I, dan Ase I pada rajungan, P. pelagicus. (M; marker, 1, Ase I; 2, Dra l; 3, Hinc l; 4, Sau 3Al; 5, tanpa pemotongan)

Figure 2. mt-DNA template digested by Sau 3Al, Dra I, Hinc I, and Ase I restriction enzymes of swimming blue crab, P. pelagicus ( $M$; marker, 1, Ase $l ; 2$, Dra $; ; 3$, Hinc $l ; 4$, Sau 3Al; 5, undigest) 


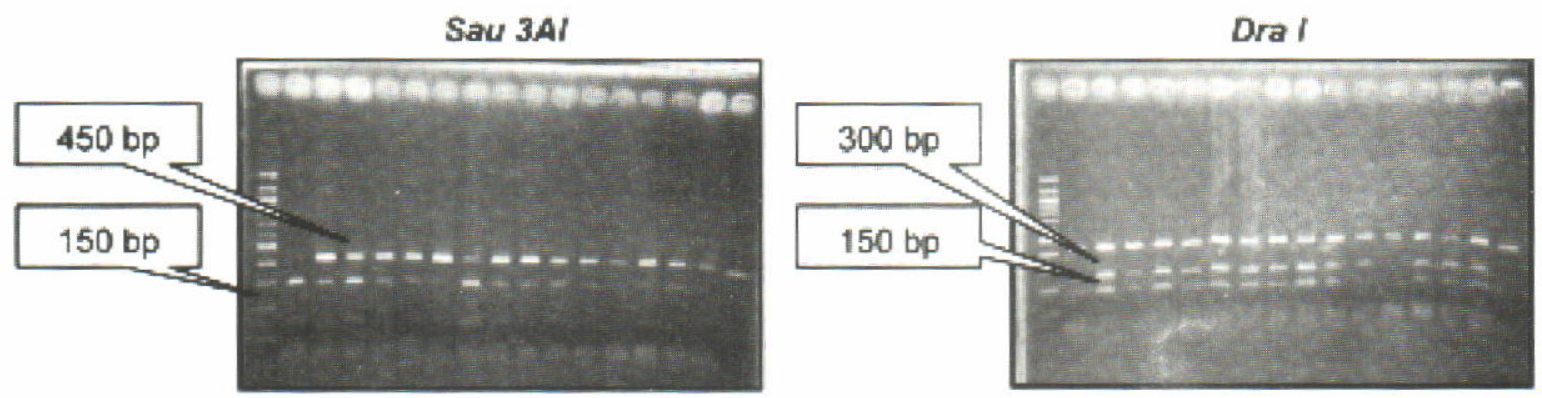

Gambar 3. Hasil pemotongan fragmen mt-DNA dengan primer Sau 3A/dan Dra / pada rajungan, P. pelagicus Figure 3. Results of endonuclease digestion of mt-DNA of swimming blue crab, P. pelagicus

Panjang untaian mt-DNA untuk masing-masing enzim restriksi dapat dilihat pada Tabel 2. Dari Tabel 2 terlihat bahwa jumlah sisi pemotongan dengan enzim Dra 1 untuk rajungan dari perairan Cilacap (Jawa Tengah) dan Jembrana (Bali) menghasilkan 2 sisi pemotongan, sedangkan untuk rajungan dari perairan P. Saugi (Sulawesi Selatan) dan Situbondo (Jawa Timur) hanya menghasilkan satu sisi pemotongan. Namun dari hasil analisis dengan Gen-pop terlihat bahwa genetic diversity dari kedua lokus yaitu Dra I dan Sau $3 A /$ ternyata lokus Dra / memberikan variasi yang lebih besar. Oleh karena itu, sebagai marka genetik dengan metode RFLP untuk rajungan dapat menggunakan enzim restriksi Dra I.

\section{Keragaman Genetik}

Keragaman genetik yang ditentukan oleh persentase lokus polimorfik tertinggi terdapat pada populasi rajungan dari perairan Cilacap, Jawa Tengah $(0,14)$; sedangkan tiga populasi rajungan lainnya menunjukkan keragaman genetik yang sama yaitu 0,09 . Nampaknya, polimorfik yang rendah pada populasi rajungan dari perairan Situbondo (Jawa Timur), Jembrana (Bali), dan P. Saugi (Sulawesi) akan diikuti dengan variabilitas genetik yang rendah pula pada ketiga populasi rajungan tersebut.

Sementara itu, jumlah alel per lokus rajungan pada populasi dari perairan Cilacap, Jawa Tengah dan Jembrana, Bali sebesar 1,18; sedangkan rajungan dari perairan Situbondo, Jatim dan P. Saugi, Sulawesi Selatan mempunyai nilai sebesar 1,09. Perbedaan jumlah alel per lokus antara populasi rajungan antara Cilacap-Jembrana dan Situbondo-P. Saugi menunjukkan bahwa populasi tersebut tidak berasal dari gene pools yang homogen. Hal ini mungkin disebabkan rintangan geografis dalam reproduksinya, yaitu 2 populasi berasal dari perairan India (Indian Ocean), sedangkan 2 populasi lainnya dari Samudera Jawa (Java Sea), sehingga individu rajungan cenderung kawin dengan lainnya dalam daerah geografis yang sama. Nilai heterosigositas tertinggi terlihat pada populasi rajungan dari Cilacap, Jawa Tengah dan Jembrana, Bali yaitu sebesar 0,004, sedangkan nilai terendah dimiliki oleh populasi rajungan dari Situbondo, Jawa Timur dan P. Saugi, Sulawesi Selatan $(0,001)$. Nilai heterosigositas yang diperoleh dari analisis mt-DNA pada umumnya relatif rendah, karena mt-DNA hanya bersifat maternal saja.

Menurut Sugama \& Hutapea (1999), nilai heterosigositas pada kepiting bakau $S$. paramamosain, S. transquebarica, dan S. olivacea masing-masing sebesar 0,$001 ; 0,011$; dan 0,036. Sementara itu, Imron et al. (1999) menyatakan bahwa heterosigositas secara positif berkorelasi dengan produktivitas dan stabilitas tropik perairan. Nilai heterosigositas rajungan dari 4 populasi yang telah dianalisis tergolong sangat rendah. Hal ini mengindikasikan bahwa populasi dengan laju migrasi yang sempit atau jarak yang pendek mempunyai

Tabel 2. Ukuran pemotongan fragmen mt-DNA rajungan dengan beberapa enzim restriksi

Table 2. Restriction size of mt-DNA fragments (base pairs) of swimming blue crab obtained after digestion with restriction enzymes

\begin{tabular}{lcccccccc}
\hline $\begin{array}{c}\text { Enzim (enzyme) } \\
\text { restriksi (restriction) }\end{array}$ & $\begin{array}{c}\text { Cilacap, } \\
\text { Jawa Tengah } \\
\text { (bp) }\end{array}$ & $\begin{array}{c}\text { P. Saugi, } \\
\text { Sulawesi Selatan } \\
\text { (bp) }\end{array}$ & $\begin{array}{c}\text { Jembrana, } \\
\text { Bali } \\
\text { (bp) }\end{array}$ & $\begin{array}{c}\text { Situbondo, } \\
\text { Jawa Timur } \\
\text { (bp) }\end{array}$ \\
\hline Dral & 300 & - & 150 & 300 & 450 & - & 300 & - \\
& 150 & 300 & - & - & 150 & 300 & - & - \\
Sau 3Al & 300 & 150 & 300 & 150 & 300 & 150 & 300 & 150 \\
\hline
\end{tabular}


Tabel 3. Keragaman genetik, heterozygosities $(\mathrm{Ho})$ dan jumlah alel per lokus dalam 22 lokus pada rajungan, P. pelagicus

Table 3. Genetic variability, heterozygosities $(\mathrm{Ho})$ and number of allele per loci $(\mathrm{Na})$ at polymorphic loci based on 22 loci of swimming blue crab, P. pelagicus

\begin{tabular}{lcccc}
\hline \multicolumn{1}{c}{$\begin{array}{c}\text { Parameter } \\
\text { Item }\end{array}$} & $\begin{array}{c}\text { Jembrana } \\
\text { (Bali) }\end{array}$ & $\begin{array}{c}\text { Situbondo } \\
\text { (Jatim) }\end{array}$ & $\begin{array}{c}\text { Cilacap } \\
\text { (Jateng) }\end{array}$ & $\begin{array}{c}\text { P. Saugi } \\
\text { (Sulsel) }\end{array}$ \\
\hline Jumlah sampel (No of sample examined) & 90 & 66 & 40 & 109 \\
Jumlah lokus (No of loci examined) & 22 & 21 & 22 & 21 \\
Jumlah lokus polimorik (No of polymorphic loci) & 2 & 2 & 3 & 2 \\
Persentase lokus polymorphic (\% polymorphic loci) & 0.09 & 0.09 & 0.14 & 0.09 \\
Jumlah alel per lokus (No of allele per locus) & 1.18 & 1.09 & 1.18 & 1.09 \\
Heterosigositas (Heterozygosity): & & & & \\
Teramati (observed) (Ho) & 0.004 & 0.001 & 0.004 & 0.001 \\
Harapan (expected) (He) & 0.004 & 0.003 & 0.004 & 0.002 \\
Ho/He & 1 & 0.333 & 1 & 0.5 \\
\hline
\end{tabular}

Ho:Average observed heterozygosity over 22 loci

He:Average expected heterozygosity

heterosigositas rendah bila dibandingkan dengan populasi yang mempunyai migrasi luas dan bersifat terbuka. Terjadinya pembatasan pertukaran gen dalam melakukan perkawinan dapat mengakibatkan perkawinan sekerabat, yang bila terjadi secara berulang-ulang dapat mengakibatkan rendahnya variasi genetik atau munculnya peluang homosigot akan lebih tinggi.

Jarak genetik yang dihitung menurut Rogers (1972), berdasarkan sisi pemotongan dari 2 enzim antara lokasi tertera pada Dendogram 1. Dendogram yang dibentuk berdasarkan jarak genetik tersebut menunjukkan bahwa antara populasi Jembrana, Bali dan Situbondo, Jawa Timur mempunyai jarak genetik terdekat yaitu 0,0013 ; sedangkan populasi P. Saugi, Sulawesi Selatan mempunyai jarak genetik paling jauh $(0,002)$ dengan jarak genetik rata-rata adalah $(0,0016)$.

Kedekatan jarak genetik antara populasi rajungan dari perairan Jembrana (Bali) dan Situbondo (Jawa Timur) mungkin disebabkan oleh genetic introgression, melalui berbagai cara (perdagangan) rajungan tersebut masuk ke perairan Bali atau sebaliknya, dan akhirnya terjadi perkembangbiakan populasi. Dari hasil tersebut diharapkan dapat digunakan sebagai acuan penggunaan induk rajungan ( $P$. pelagicus) untuk breeding dan pembenihan agar diperoleh benih yang berkualitas.

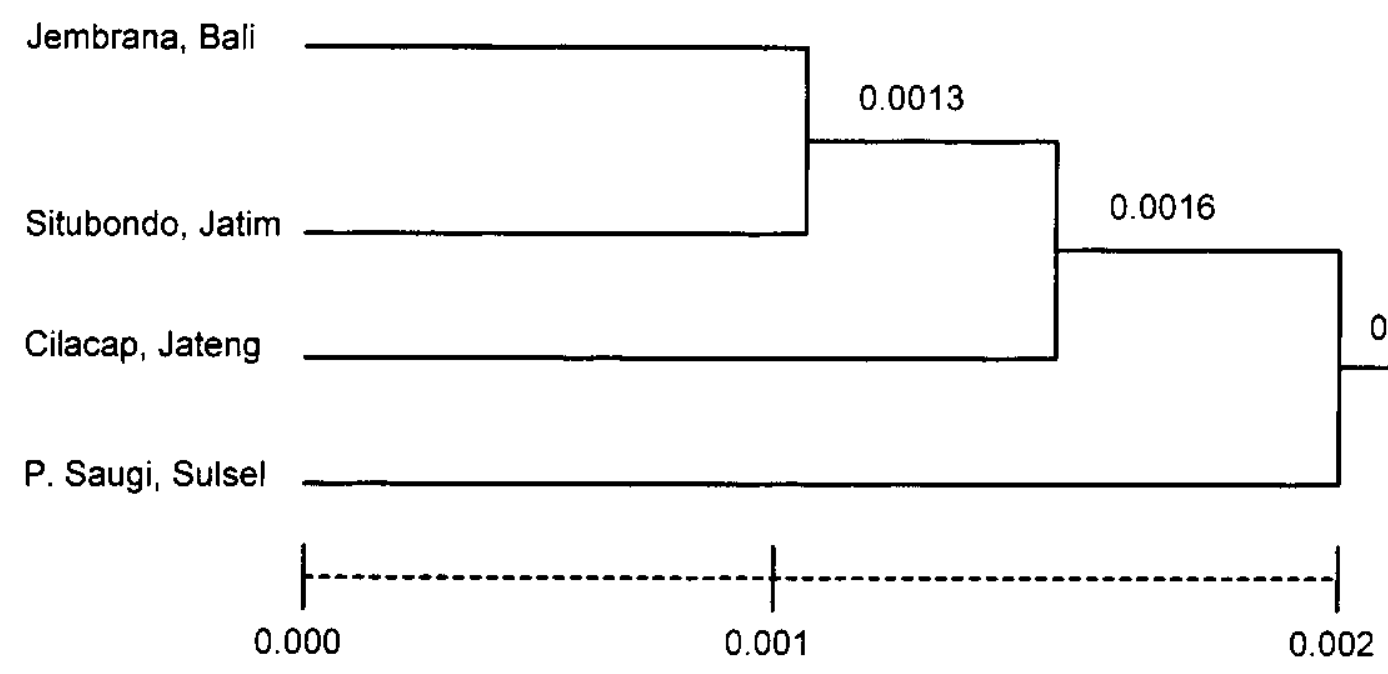

Dendogram 1. Jarak genetik rajungan, P. pelagicus (Rogers, 1972)

Dendogram 1. Genetic distance of swim blue crab, P. pelagicus (Rogers, 1972) 


\section{KESIMPULAN}

1. Enzim restriksi Dra / dapat digunakan sebagai marker genetik rajungan pada tingkat molekuler dengan metode RFLP mt-DNA.

2. Keragaman genetik dengan nilai heterosigositas tertinggi terdapat pada populasi rajungan dari perairan Cilacap (Jawa Tengah).

3. Populasi Jembrana (Bali) dan Situbondo (Jawa Timur) mempunyai pasangan alel yang hampir sama dengan jarak genetik yang dekat $(0,0013)$ sedangkan populasi P. Saugi, Sulawesi Selatan mempunyai jarak genetik paling jauh $(0,002)$ terhadap 3 populasi lainnya.

\section{DAFTAR PUSTAKA}

Benzie, J.A.H. and S.T.W. Williams. 1996. Limitation of The Genetic Variation of Hatchery Produced Bathes of Giant Clam; Tridacna gigas. Aquaculture, 139: 225-241.

Imron, K. Sugama, K. Sumantadinata, and K. Soewardi. 1999. Genetic variation in cultured stocks of tiger shrimp (Penaeus monodon) in Indonesia. IFR Journal, V(1): 10-18

Juwana S. 2002. Crab culture technique at RDCO-LIPI, Jakarta, Indonesia 1994 to 2001. Proceeding workshop on mariculture in Indonesia Mataram, Lombok /sland. Research Center for OceanographyLIPI, Institute of Marine Research Norwegian BerenNorway, p. 49-60.

Leary, F.L., F.W. Allendorf, and K.L. Knudsen. 1985. Developmental Instability as an Indicator of Reduced Genetic Variation in Hatchery Trout. Trans. Am. Fish. Soc., 114: 230-235.

Ovenden, J. 2000. Development of Restriction Enzyme Markers for Red Snapper (Lutjanus erythropterus and Lutjanus malabaricus) Stock Discrimination Using Genetic Variation in Mitochondria DNA. Molecular Fisheries Laboratory, Southern Fisheries Centre, 18 pp.
Raymand, N. and G. Stahl. 1980. Genetic Change in Hatchery Stocks of Brown Trout (Salmon trout). Canadian. J. of Fish. Aqua. Scien., 37: 82-87.

Raymond, M. and F. Rousset. 1995. GENEPOP (Version 1.2): Population Genetic Software for Exact Test and Ecumenicism. J. Hered, 86: 248-249.

Rogers, J.S. 1972. Measures of genetic similarity ang genetic distance, p. 145-153. In Studies in genetics. VII.Ed.M.R.Wheeler Univ. Texas Publ.7213, 354 pp.

Rusdi, I., A. Parerengi, dan D. Makatutu. 1993. Pengaruh perbedaan salinitas terhadap penetasan dan kelangsungan hidup zoea awal kepiting bakau, Scylla serrata. J. Pen. Budidaya Pantai, 9(1): 141-146.

Rusdi, I. 1999. Pengaruh pengkayaan rotifer terhadap sintasan dan perkembangan kepiting bakau, Scylla serrata skala laboratorium. Prosiding Seminar Nasional Puslitbangkan bekerjasama dengan JICAATA 379, p. 173-178.

Sugama, K. and A. Prijono.1998. Biochemical genetic differentiation among wild populations of Milkfish (Chanos-chanos) in Indonesia, IFR Journal, IV(1): $11-18$

Sugama, K. and J.H. Hutapea. 1999. Genetic Characterization in Mud Crab Scylla (Brachyura Portunidae). In Keenan, C.P. and A. Blackshaw (Eds.) Mud Crab Aquaculture and Biology. ACIAR, Canberra, p. $43-48$.

Supriyatna, A. 1999. Pemeliharaan larva rajungan, Portunus pelagicus dengan waktu pemberian pakan artemia yang berbeda. Prosiding Seminar Nasional Puslitbangkan bekerja sama dengan JICA-ATA 379, p. $168-172$.

Sokal, R.R. and R.G. Rohlf. 1981. Biometry. Freeman and Co. San Francisco. California, 776 pp

Taniguchi, N., K. Sumantadinata, and S. Iyama. 1983. Genetic change in the first and second generation of hatchery stock of black sea bream. Aquaculture, 35 : 309-320.

Yunus, K. Suwirya, Kasprijo, dan I. Setyadi. 1996. Pengaruh pengkayaan rotifer (Brachionus plicatilis) dengan menggunakan minyak hati ikan cod terhadap sintasan larva kepiting bakau, Scylla serrata. J. Pen. Per. Indonesia, 2(3): 38-45. 